\title{
Corrosion Level of Rock Bolts Exposed to Aggressive Environments in Nordic Road Tunnels
}

\author{
Cristobal Javier Manquehual $^{1}$ (1) $\cdot$ Pål Drevland Jakobsen $^{1} \cdot$ Amund Bruland $^{1}$
}

Received: 12 February 2021 / Accepted: 14 June 2021 / Published online: 30 June 2021

(c) The Author(s) 2021

\begin{abstract}
For road tunnels in most Nordic countries, temporary rock support installed during tunnel excavation usually becomes a part of the permanent rock support. Rock bolts are the most common rock support measure in road tunnels excavated in hard rock, and their conditions over the period of tunnel operation play a significant role in the safety of these tunnels. The rock bolt types and aggressive environmental conditions considered in this research are focused on those used and observed in Norwegian and Swedish road tunnels. Findings elsewhere in similar environments are included to highlight the different kinetics of degradation. Based on the collected data, the corrosion levels in these road tunnels are comparable to those in the most polluted industrial areas. Aggressive groundwater conditions for rock bolts include a groundwater $\mathrm{pH}$ below four (which can be caused by sulfuric acid formation due to the oxidation of the mineral pyrite in the rock), marine groundwater, and flowing groundwater with a high concentration of dissolved oxygen. Furthermore, chloride-bearing deicing salts commonly used on roads located in cold climate regions during winter can promote corrosion in rock bolts from the tunnel room. For these environments, this research proposes a lognormal probability function to quantify the expected steel corrosion level for 25,50 , and 100 years of exposure time. The corrosion protection given by cement grouting, hot-dip galvanizing and epoxy coating are also addressed to explore their contributions to the lifespan extension of rock bolts in acidic and chloride-rich environments.
\end{abstract}

Keywords Rock bolt $\cdot$ Rock support tunnel $\cdot$ Durability $\cdot$ Corrosion $\cdot$ Probability of failure

\section{List of Symbols}

$b \quad$ Empirical constant related to the penetration rate of an acidic solution in cement grout $\left(\mathrm{mm} /\right.$ year $\left.^{0.5}\right)$

$b_{e} \quad$ Environmental transfer, which considers the influence of $T_{\text {real }}$ on the apparent diffusion coefficient $(\mathrm{K})$

$C\left(x_{c}, t\right) \quad$ Chloride content in grout mortar by weight of cement at depth $x_{c}$ and elapsed time $t$ (wt $\%$ cement)

$C_{s} \quad$ Initial chloride loading concentration at the rock-grout interface (wt\% cement)

$d \quad$ Degradation depth in the grout mortar by acidic solution attack $(\mathrm{mm})$

\begin{tabular}{|c|c|}
\hline$D_{\text {app }}\left(t, T_{\text {real }}\right)$ & $\begin{array}{l}\text { Apparent coefficient of chloride diffusion } \\
\text { through the grout mortar after elapsed times } \\
t \text { and } T_{\text {real }}\left(\mathrm{m}^{2} / \mathrm{s}\right)\end{array}$ \\
\hline$D_{\text {app_28 }}$ & $\begin{array}{l}\text { Theoretical coefficient of chloride diffusion } \\
\text { after } 28 \text { days }\end{array}$ \\
\hline$D_{\text {paint }}$ & $\begin{array}{l}\text { Years of protection by direct application of } \\
\text { the epoxy coating on carbon steel }\end{array}$ \\
\hline$D_{\text {zinc }}$ & $\begin{array}{l}\text { Years of protection by hot-dip galvanizing } \\
\text { on carbon steel }\end{array}$ \\
\hline$i$ & $\begin{array}{l}\text { Ranking position of an observed value once } \\
\text { the set sample has been sorted from the low- } \\
\text { est to the highest values }\end{array}$ \\
\hline$K$ & $\begin{array}{l}\text { Synergistic factor for carbon steel protection } \\
\text { by the duplex protection system of hot-dip } \\
\text { galvanizing and epoxy coating }\end{array}$ \\
\hline$k$ & $\begin{array}{l}\text { Corrosion rate of metals in the first year } \\
(\mu \mathrm{m} / \text { year })\end{array}$ \\
\hline$n$ & $\begin{array}{l}\text { Metal-environment time exponent param- } \\
\text { eter for corrosion rate }\end{array}$ \\
\hline$N$ & Sample size of random observations \\
\hline
\end{tabular}
through the grout mortar after elapsed times $t$ and $T_{\text {real }}\left(\mathrm{m}^{2} / \mathrm{s}\right)$ after 28 days Years of protection by direct application of the epoxy coating on carbon steel Years of protection by hot-dip galvanizing on carbon steel Ranking position of an observed value once the set sample has been sorted from the lowest to the highest values by the duplex protection system of hot-dip galvanizing and epoxy coating Corrosion rate of metals in the first year ( $\mu \mathrm{m} /$ year)

Cristobal Javier Manquehual

cristobal.j.manquehual@ntnu.no

Department of Civil and Environmental Engineering, Norwegian University of Science and Technology, Høgskoleringen 7A, 7034 Trondheim, Norway 


\begin{tabular}{|c|c|}
\hline$N(\mu ; \sigma)$ & $\begin{array}{l}\text { Normal distribution with mean } \mu \text { and stand- } \\
\text { ard deviation } \sigma\end{array}$ \\
\hline$t$ & Time elapsed (year) \\
\hline$t_{o}$ & $\begin{array}{l}\text { Reference time for the known value of the } \\
\text { apparent coefficient of chloride diffusion; } \\
\text { as the reference chloride diffusion is taken } \\
\text { after } 28 \text { days, } t_{o} \text { is } 0.077 \text { (year) }\end{array}$ \\
\hline$T_{\text {real }}$ & $\begin{array}{l}\text { Representative long-term cement grout } \\
\text { temperature }\left({ }^{\circ} \mathrm{C}\right)\end{array}$ \\
\hline$w / c$ & Water-cement ratio in grout mortar \\
\hline$x_{c}$ & $\begin{array}{l}\text { Distance from the borehole contour to the } \\
\text { rock bolt surface (annulus grout thickness) } \\
\text { (mm) }\end{array}$ \\
\hline$\alpha$ & $\begin{array}{l}\text { Aging exponent of the apparent chloride } \\
\text { diffusion coefficient }\end{array}$ \\
\hline
\end{tabular}

\section{Introduction}

Rock bolts can be used in underground structures as rock support for several purposes. In hard rock with low to moderate in situ stresses, rock bolts hold loose blocks and contribute to increasing the rock mass stiffness (Bobet 2009). In hard rock with high in situ stresses, rock bolts prevent failed rock from disintegrating if they are able to absorb the kinetic energy of the ejected rock ( $\mathrm{Li} 2017 \mathrm{a}$ ). In highly stressed soft rock, rock bolts deform with the rock mass until an equilibrium is reached and deformation ceases (Li 2017a). Regardless of the reason for utilizing rock bolts in underground structures, they are usually made of carbon steel and are therefore susceptible to corrosion. This chemical process causes steel to lose its cross-sectional area and form corrosion products on its surface due to interactions with the environment. Consequently, corrosion can reduce the strength capacity of rock bolts and diminish the bond strength with the surrounding material over time (Xia et al. 2013; Dorion and Hadjigeorgiou 2014). The rate at which this rock bolt corrosion proceeds depends on the chemical composition of the steel, the type of anchorage system, the type of corrosion protection, the quality control during installation, the environmental conditions where they are exposed and any increase in stress demand caused by the rock mass over time (Hadjigeorgiou et al. 2020).

The consequence of corrosion on rock bolts with a higher probability of failure over time can be visualized in Fig. 1. This figure shows the general principles of the probabilistic limit-state approach for the durability design of structures according to the standard ISO 138232008 . In this approach,

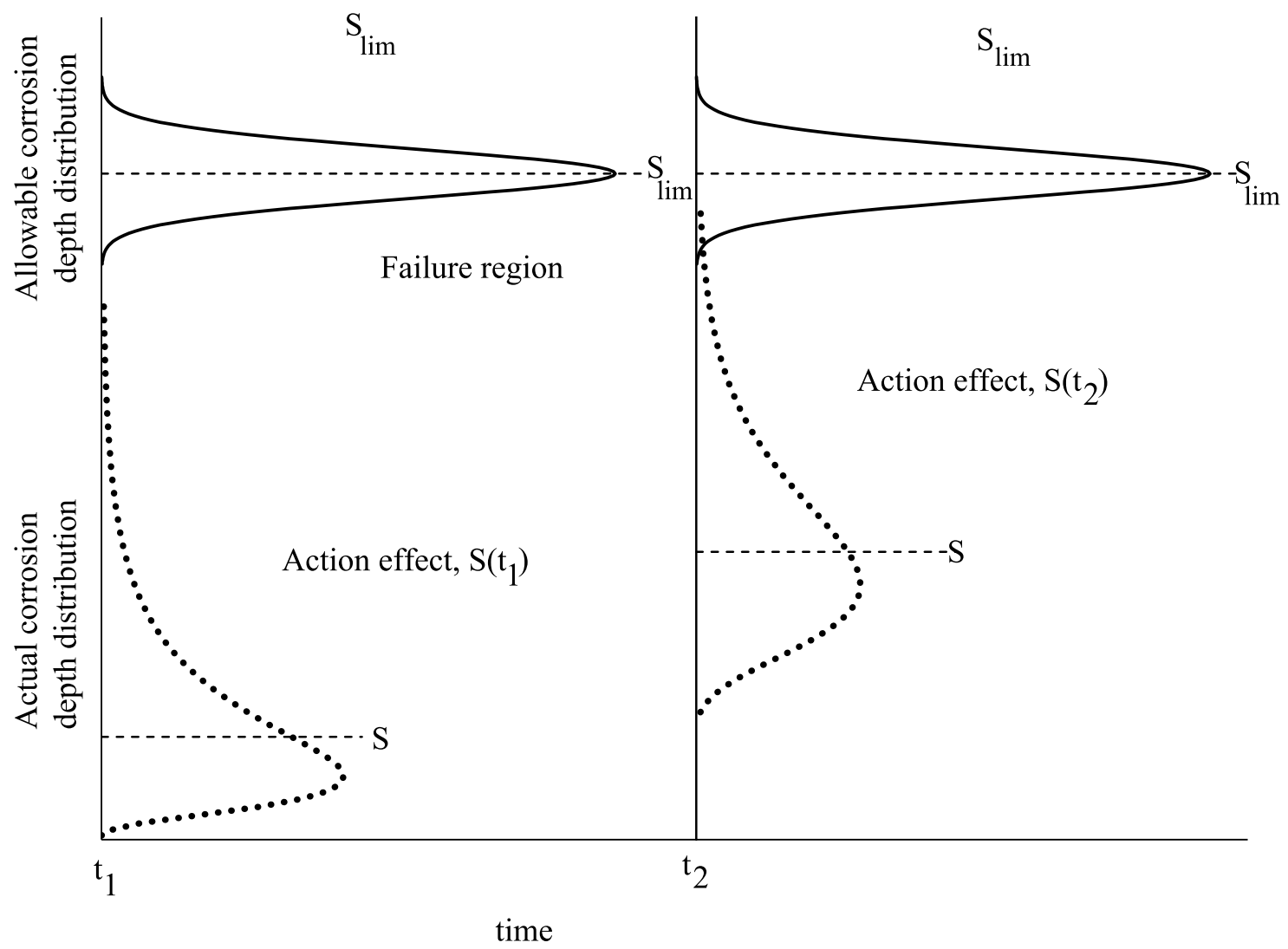

Fig. 1 Probabilistic limit-state approach for predicting the useful life applied to rock bolt corrosion. Modified from standard ISO 13823 (2008) 
an appropriate probability distribution is assigned to both the allowable corrosion depth $S_{\text {lim }}$ and the action effect $S$ for a specific exposure time. In this context, corrosion increases the probability of failure once the probability distribution curve of the action effect increases to such a level that it starts to overlap with the allowable corrosion depth curve. This failure region, highlighted as the shaded area in Fig. 1, is related to the probability of failure. For simplicity, Fig. 1 does not show changes in the allowable depth distribution over time. However, time-dependent geohazards, such as swelling or squeezing, aggravate the situation with an increasing load exerted by the rock mass over time (Stille and Palmström 2018).

The role of rock bolts as rock support in road tunnels is critical in not only Norway, but also Sweden, Finland, Iceland and the Faroe Islands. These tunnels, in comparison to those in many other countries, do not consider in principle a thick inner lining of cast-in-place concrete. If water and frost protection are needed, an inner lining detached from the rock support is installed. This slender inner lining is held by fixation bolts anchored directly to the rock mass (Broch et al. 2002). Figure 2 aims to show this layout solution with an inner lining of precast concrete segments typically used in Norwegian road tunnels with high traffic volume. In addition, some environmental parameters are indicated in the same figure.

Figure 2 shows the key role of temporary (and permanent) rock support in the safety of road tunnels with this layout. It also describes some atmospheric and aqueous environmental parameters that may affect the longevity of rock bolts. In current Norwegian regulations, the useful life of permanent rock support must be 100 years regardless of the actual

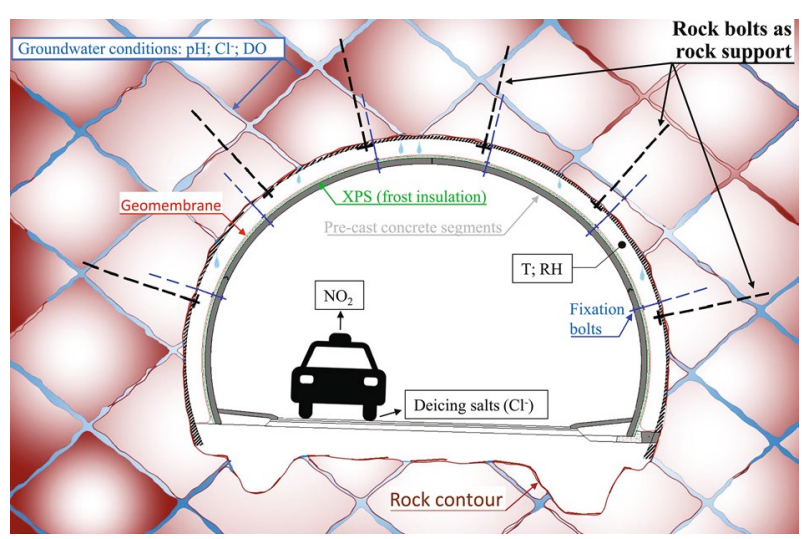

Fig. 2 Pre-accepted solution in Norwegian road tunnels with an inner lining modified from NPRA (2016a). The following atmospheric parameters are also included: temperature $(\mathrm{T})$, relative humidity $(\mathrm{RH})$ and nitrogen dioxide $\left(\mathrm{NO}_{2}\right)$. In groundwater: $\mathrm{pH}$, chloride content $\left(\mathrm{Cl}^{-}\right)$and dissolved oxygen concentration (DO)

environmental conditions (NPRA 2016a). As a comparison, in Sweden, the Swedish Transport Administration (2016) stipulates a useful life requirement of 120 years for rock support systems.

The determination of the useful life of rock bolts by a probabilistic modeling requires a probability distribution for the action effect $S$, a probability distribution for the allowable corrosion depth $S_{\text {lim }}$ and a target probability of failure. The basis of the structural design in the European standard EN 1990:2002 differentiates the structures by reliability classes according to the consequences of failure. In this ranking, the consequences classes $\mathrm{CC} 1, \mathrm{CC} 2$ and $\mathrm{CC} 3$ represent low, medium, and high failure consequences respectively and are linked to the reliability classes RC1, RC2 and RC3. Later, the model code for service life design (fib 2006) specified reference values of the probability of failure for the different reliability classes. In particular, for the ultimate limit state in reliability class RC2, a failure probability value on the order of $10^{-5}$ is recommended, while for reliability class RC3, a failure probability value on the order of $10^{-6}$ is recommended. More recently, Stille and Palmström (2018) suggested placing low to medium traffic tunnels within consequence class $\mathrm{CC} 2$, and heavy traffic tunnels in consequence class CC3. Then, it is possible to say that the available literature provides target failure probabilities.

In regard to modeling the action effect of corrosion in rock bolts, the situation is different. Although there has been research presented on rock bolt conditions in the field and the kinetics of degradation studies in the laboratory, there has been insufficient progress in the literature to systematize the different findings and quantitatively improve the longterm design of rock bolts.

Classification systems aiming to rank the corrosion level of rock bolts in underground structures by identifying key environmental parameters have been proposed ( $\mathrm{Li}$ 2000; Roy et al. 2016). However, there is no link between these classification systems and expected useful lives of various types of rock bolts.

On the other hand, reference values of the useful lives of different types of rock bolts have been given in the literature (Helfrich 1989; Pells and Bertuzzi 1999). However, the characterization of the environment in which these useful lives can be achieved is not specified.

This paper first describes the aggressive environments observed in Nordic road tunnels and synthesizes the corrosion level of carbon steel in these environments. Thereafter, the resulting description of the kinetics of steel corrosion is compared with international standards to contextualize the corrosion observed. In addition, this paper aims to derive a probabilistic distribution for the action effect $S$ caused by corrosion on rock bolts in aggressive environments based on the observed kinetics. Finally, an assessment is performed for the corrosion protection of rock bolts given by cement grouting, hot-dip galvanizing, 
and epoxy coating in different aggressive environments to elucidate their contribution.

\subsection{Evolution of Specifications Aimed at Improving the Durability of Rock Bolts in Norway}

Cement grouted rebar bolts were introduced before the 1970s in road tunnels (Grimstad and Pedersen 1986). Practitioners in the early 1970s already agreed that rock bolts should be embedded in cement mortar (see Fig. 3a) to be considered part of the permanent rock support (KFF 1973). At that time, the rebars used were uncoated, and generally, they were installed far behind the tunnel face and not tensioned. This means that they were passive rock bolts, being the working load immediately after installation negligible. Thus, their full-strength capacity was available for long-term support.

Galvanized bolts have been used for corrosion protection in Norway since 1970 (Martinussen 2008). In the first Standard Code of Process (NPRA 1981), each rebar bolt was required to be fully grouted and galvanized $(80 \mu \mathrm{m}$ thickness). However, concerns about the eventual corrosion of zinc under the alkaline environment provided by cement mortar motivated further changes in technical specifications. The recommendations by the Norwegian road authority in the northern region to the first national handbook stated that fully grouted bolts with hot-dip galvanized coatings can be used as permanent supports as long as either the mortar held soluble chromates or bolts were passivated with chromate compounds (NPRA Northland 1990). However, some years later, the Norwegian Labor Inspection Authority set requirements for a low content of soluble chromates to reduce allergies of workers (NPRA 1999).

The duplex protection system of hot-dip galvanizing and the epoxy coating was added as a requirement in 1992 for all rock bolts installed in very corrosive environments (NPRA 1992). Today, its use has been extended to all rock bolts installed in road tunnels, regardless of the actual environmental conditions. Notably, in recent years, the minimum average thickness of epoxy coatings has increased. Between 2012 and 2018, the thickness specifications of epoxy coatings increased from $60 \mu \mathrm{m}$ to $85 \mu \mathrm{m}$ (NPRA 2012, 2018). In addition, quality control measures have been introduced in the current regulations, where no single measurement shall (a)

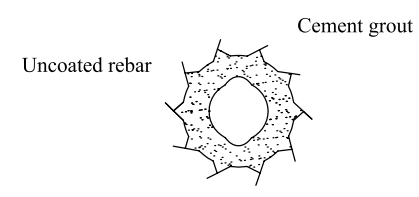

(b)
Steel pipe hot-dip galvanized and epoxy coated Cement grout

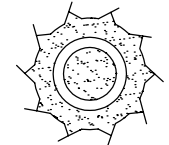

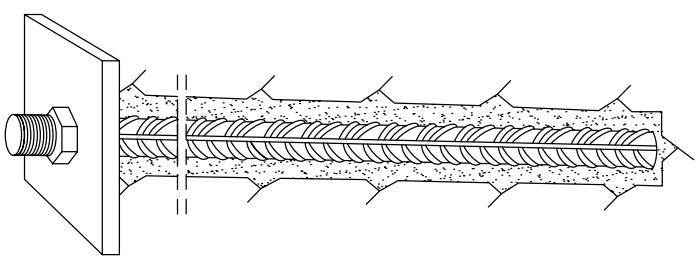

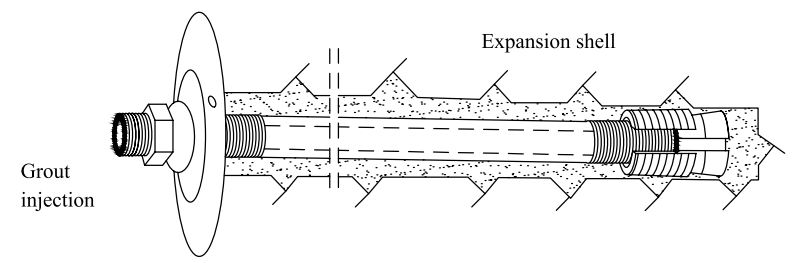

Rebar hot-dip galvanized and epoxy coated Cement grout
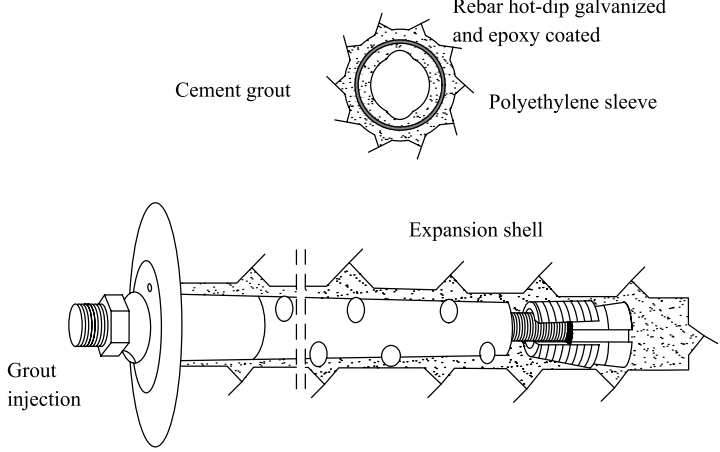

Fig. 3 Some rock bolts used as permanent rock supports in Norwegian road tunnels. a Uncoated rebar cement grouted in the Haukeli road tunnel constructed between 1968 and 1969. The rebar is 20 $\mathrm{mm}$ in diameter and $2.4 \mathrm{~m}$ long (Pedersen and Hafsaas 1991). b Pipe bolt used in Byfjord and Mastrafjord subsea road tunnels constructed between 1989 and 1992. The 3-m-long rock bolt, steel pipe and accessories are hot-dip galvanized and epoxy coated (Espedal and Nærum 1992). c CT-Bolt used in the Frøya subsea road tunnel constructed between 1998 and 2000. The 3-m-long rock bolt, rebar and accessories are hot-dip galvanized and epoxy coated (Holmøy et al. 2009) 
be thinner than $20 \mu \mathrm{m}$ (NPRA 2018). Figure 3b, c show two types of rock bolts with a duplex protection system. These rock bolts are used as temporary and permanent rock supports. They are usually installed close to the tunnel face and tensioned to $30-50 \mathrm{kN}$ with the expansion shell placed at the distal end of the rock bolt (NPRA 1999). At a later stage, they are postgrouted. Taking into account that the ultimate tensile strength of pipe bolts (Fig. 3b) is on the order of $130 \mathrm{kN}$, while that for a CT bolt (Fig. 3c) is $150 \mathrm{kN}$, the initial working stresses in these rock bolts are in the range of $20-40 \%$ with respect to their ultimate tensile strength. Furthermore, these rock bolts will undergo additional loads if installed near the tunnel face due to the remaining stresses in the rock mass that are not released until the tunnel face has advanced further ahead. Thus, the pre-tensioning and the installation near the tunnel face make pipe and CT rock bolts lose a fraction of their long-term strength capacity. In turn, this loss limits the allowable corrosion that they can undergo.

\section{Aggressive Environmental Conditions}

Several approaches have been proposed in the literature regarding the selection of relevant environmental parameters to explain the corrosion level in metals, such as the German standard DIN 50929 part 3 (1985). There are also specific efforts to identify key environmental parameters affecting the corrosion of rock bolts ( $\mathrm{Li} 2000$; Roy et al. 2016). These three references coincide in the following water properties as relevant:

- $\mathrm{pH}$

- Salinity (according to either the $\mathrm{Cl}^{-}$and $\mathrm{SO}_{4}{ }^{2-}$ content, electrical resistivity, or total dissolved solids in groundwater)

- Concentration of dissolved oxygen

Regarding the $\mathrm{pH}$ in groundwater, the three just-mentioned references agree that a $\mathrm{pH}$ of water below four is an important water property to promote corrosion. In Norway, such a low $\mathrm{pH}$ level has been measured in tunnels excavated in alum shale rock (NPRA 2016b). This rock contains the mineral pyrite $\left(\mathrm{FeS}_{2}\right)$, which under the presence of oxygen and water, it oxidizes creating sulfuric acid. Water samples in tunnels excavated in alum shale have measured $\mathrm{pH}$ values between two and three, and sulfate ion concentrations between 300 and $3000 \mathrm{mg} / \mathrm{l}$ (Hagelia 2018).

A high chloride content has been identified in the groundwater of subsea tunnels. The results of 40 water samples from different subsea tunnels indicate that the chloride concentration range is between $1000 \mathrm{mg} / \mathrm{l}$ and $50,200 \mathrm{mg} / \mathrm{l}$, with an average close to $19,000 \mathrm{mg} / \mathrm{l}$ (Hagelia 2008). With this concentration level, subsea tunnels fall into the highest salinity level in all the rankings mentioned.

The occurrence of high concentrations of dissolved oxygen is expected in Nordic underground structures due to a general low groundwater temperature $\left(<7^{\circ} \mathrm{C}\right)$ (Kløve et al. 2017). Although dissolved oxygen content in groundwater generally decreases with depth, high concentrations can be found at deep depths if the aquifer is permeable and connected to a brook (Seither et al. 2012). Thus, Nordic underground structures with permeable rock and low overburden are susceptible to have groundwater with high concentrations of dissolved oxygen.

\subsection{Specific Atmospheric Environmental Conditions in Road Tunnels}

Chlorides contained in deicing salts for roads are usually used in cold climate regions. The effect of traffic volume on chloride dispersion in road tunnels has been described in durability studies of sprayed concrete used for rock support. Studies on the measurement of salt deposition on the outer surface of sprayed concrete layers show that high salt concentrations have been systematically found on tunnel walls within the first $2 \mathrm{~m}$ from the road level (Davik 1997). Above $2 \mathrm{~m}$, chloride ion deposition remains high only in road tunnels with high traffic volume (Hagelia 2018).

With regard to relative humidity, Knudsen (2015) highlights the humid environment observed in Norwegian road tunnels, especially behind water and frost protection linings, where it can be close to $100 \%$.

High concentrations of pollutants, particularly emitted by vehicles, exist in road tunnels (NILU 1990; Indrehus and Vassbotn 2001). $\mathrm{NO}_{2}$ gas has been described as a moderate atmospheric corrosive agent for steel (iron) and zinc (Castaño et al. 2007; Leygraf et al. 2016). Research in road tunnels in Sweden has downgraded the influence of $\mathrm{NO}_{2}$ gas on corrosion (Andersson and Sandberg 2003). This is because pollutants are ubiquitous in the air, yet significant differences in corrosion rate have been observed in the sides of flat metal sheets along the roads; the corrosion rate is much higher for the metal sheets facing the traffic.

Figure 4 shows the case of a rock bolt whose accessories and the protruding end of the rebar are corroded.

\section{Probability Distribution of the Actual Corrosion Depth in Steel}

Both uniform and localized (pitting) corrosion have been described in rock bolts installed in underground structures. Figure 5 summarizes the highest corrosion levels of carbon steel reported in nine underground structures in Nordic countries. Further details about these underground structures are 
described in Table 1. Figure 5 shows 11 corrosion observations because in two underground structures, corrosion measurements took place in two different years. The collected data come from mainly rebars with grout defects and rock bolt ends protruding from the tunnel contour. Apart from examples from Norwegian and Swedish road tunnels, some other corrosion data from underground structures are given to complement the scarce long-term exposure data found in road tunnels.

International standards NS-EN ISO 9224 (2012) and NSEN-ISO-9223 (2012) provide guiding values for the uniform corrosivity level that metals can undergo depending on the

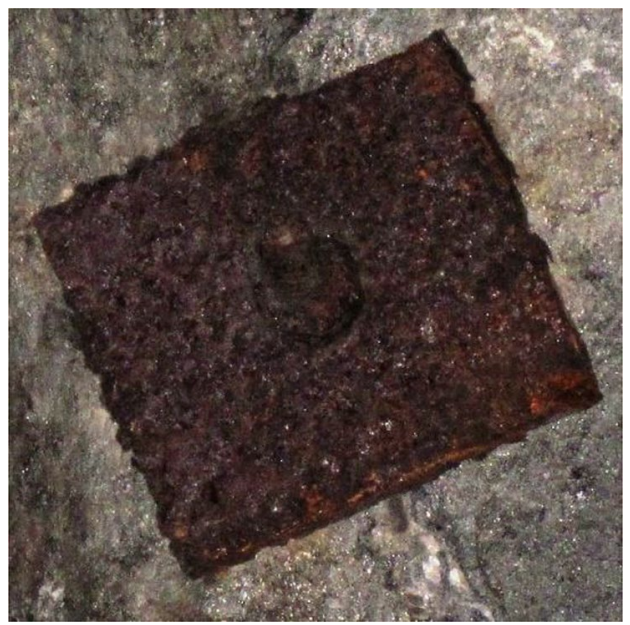

Fig. 4 Fully grouted uncoated rebar with unprotected steel accessories in the Hamregjøl tunnel after 47 years in service (Ongstad 2012) atmosphere to which they are exposed. In these international standards, the highest corrosivity category is the so-called extreme corrosivity level CX, which is related to the most polluted industrial areas. Eq. 1 provides the general corrosion rate prognosis in metals given in international standards as follows:

$D=k \cdot t^{n}(\mu \mathrm{m})$.

In particular, for carbon steel exposed to the extreme corrosivity level CX, the parameter $k$ varies between 200 and $700 \mu \mathrm{m} /$ year. The parameter $n$, which is usually less than 1 , may be related to the inhibition of substrate corrosion by the growing oxide film on the surface over time. For carbon steel, the average value of parameter $n$ is 0.52 . The use of these values in Eq. (1) are plotted in Fig. 5 to represent the most severe corrosivity category given in international standards as a comparison to the corrosion observed in Nordic underground structures.

The kinetics of pitting corrosion has been described in steel buried in soils by Romanoff (1957) and Melchers and Petersen (2018) via Eq. (1). For pitting corrosion, while the parameter $n$ varies between 0.44 and 0.58 , the parameter $k$ varies between 732 and $843 \mu \mathrm{m} /$ year.

Based on these reference values, the time-exponent parameter $n$ between uniform and localized corrosion is similar. With regard to the first-year corrosion rate $k$, pitting corrosion provides values similar to the upper bound of the extreme corrosivity level CX. The similarity in magnitude between uniform and localized corrosion has also been reported by Andersson and Sandberg (2003) during the

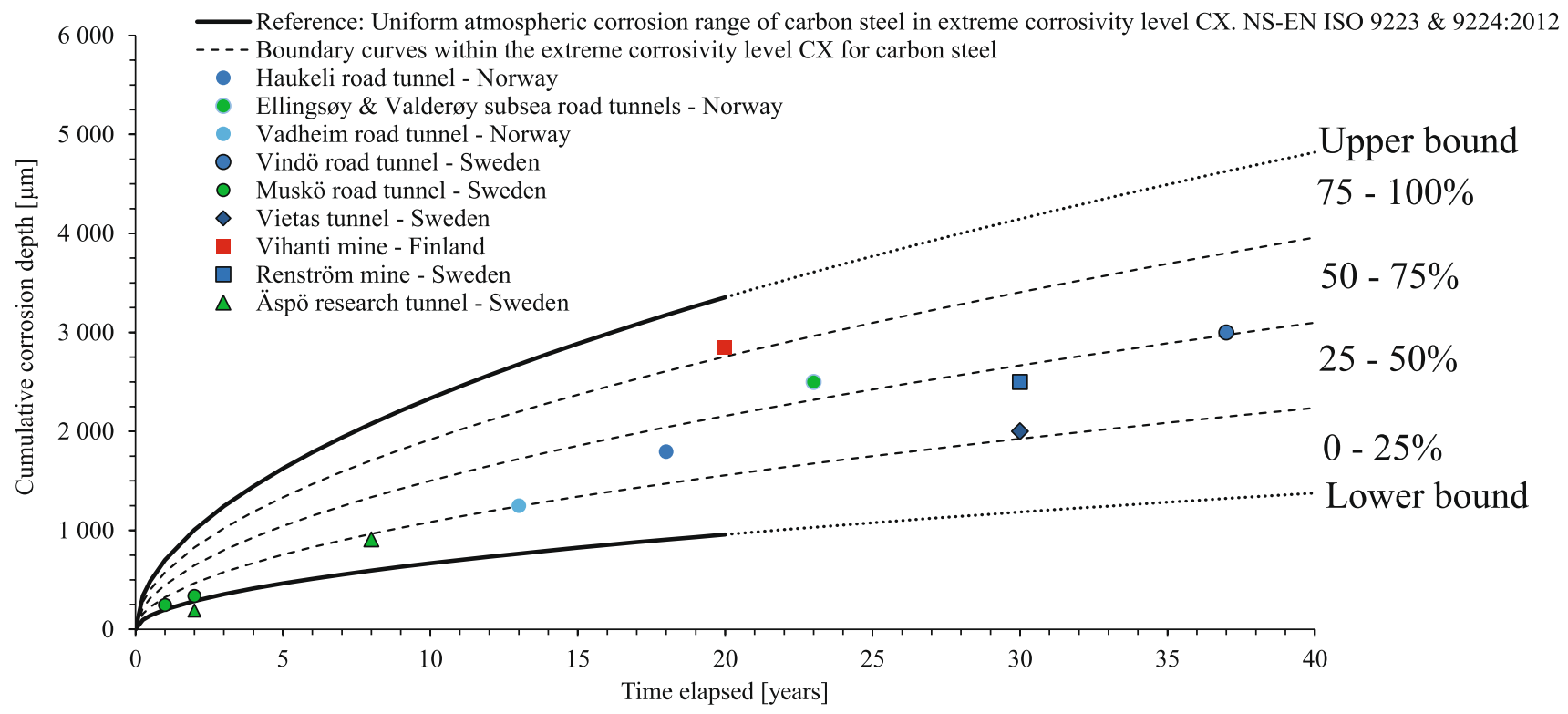

Fig. 5 Long-term collection of corrosion progression on carbon steel in different underground structures. Blue and light blue dots reflect dripping/flowing water as the presumably predominant corrosion environment. Green dots represent chloride-rich groundwater. Red dot reflects a sulfide-rich environment with presumably low $\mathrm{pH}$ 


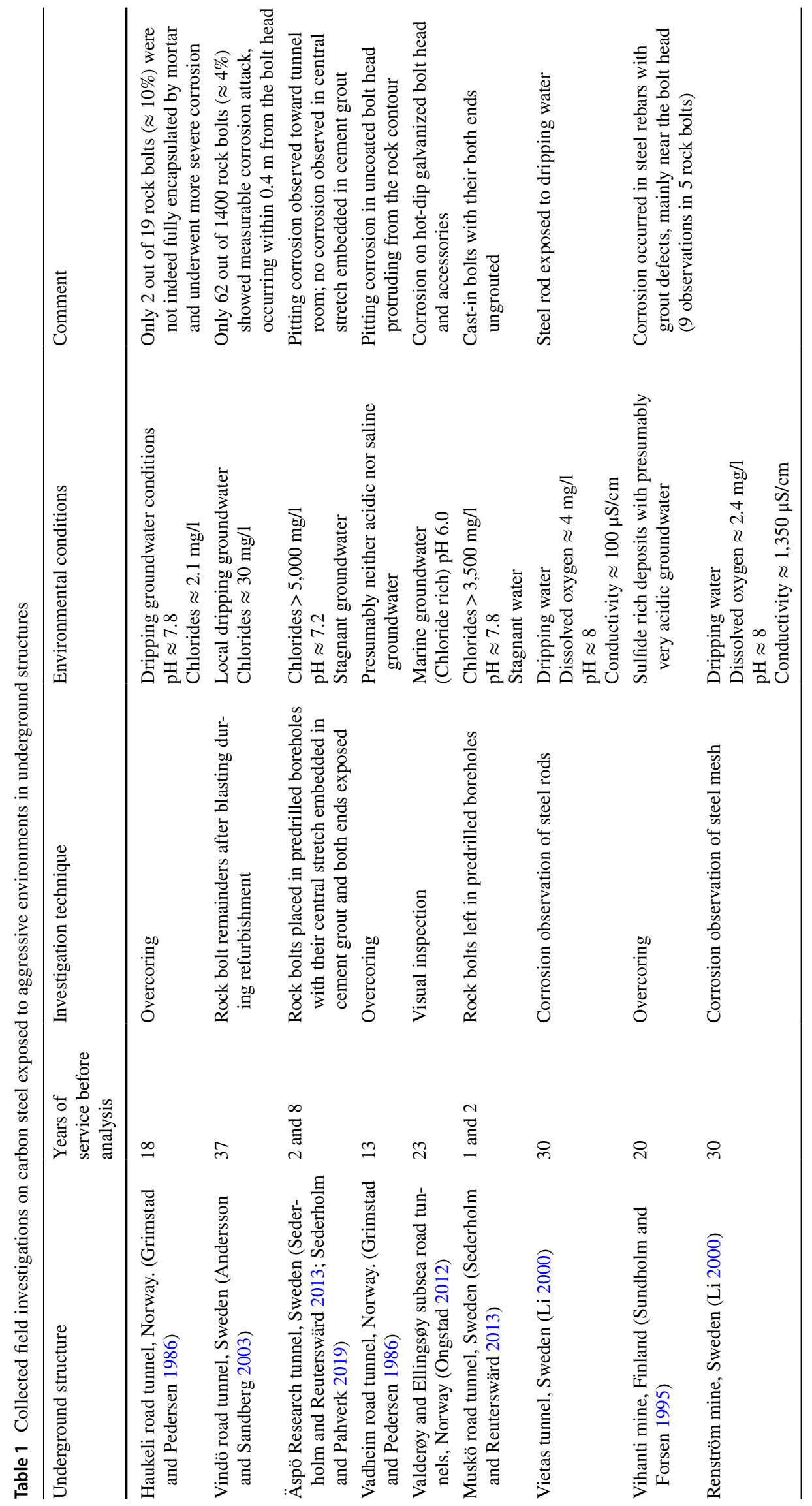


refurbishment of the Swedish road tunnel Vindö. This indicates a general blunt metal-loss defect in carbon steel over time, allowing uniform and localized corrosion observations to be plotted in a single chart.

Figure 5 shows that 10 out of the 11 long-term corrosion observations on carbon steel are within the range established for the extreme corrosivity level CX. This is equivalent to an approximately $91 \%$ confidence level for the corrosion observations shown in Fig. 5. This trend arises in observations from different aggressive environments, underground structures, and exposure times. Thus, this research will use this band as the expected corrosion depth range on carbon steel for longer exposure times in underground structures. Then, it is assumed that the corrosion kinetics of the carbon steel given in Eq. (1) will persist in the long-term. In addition, a confidence level of $91 \%$ will be extrapolated for longer exposure times (this corresponds to a $9 \%$ significance level for longer exposure times).

The following step is to find a suitable probability distribution. In this regard, Fig. 5 shows that most of the observations are closer to the lower bound of the extreme corrosivity level $\mathrm{CX}$. To quantify this observation, three subdivisions are introduced for this corrosivity level. These subdivisions are evenly spaced for a given exposure time. The aim is to create a histogram based on the intervals shown on the right-hand side of Fig. 5 to reflect the distribution of the corrosion observations. Figure 6 shows the resulting histogram, where zero represents the lower bound and one represents the upper bound defined in Fig. 5.

Figure 6 includes the 10 corrosion observations within the extreme corrosivity level CX. The results show a higher density towards the lower bound, where seven out of the 10 observations lie below the median or 50th percentile. This suggests that a lognormal probability function might fit the corrosion observations classified for the different intervals of the extreme corrosivity level CX. In fact, the international standard NSEN-ISO-9223 (2012) states that the corrosion rates of metals usually follow a lognormal distribution.

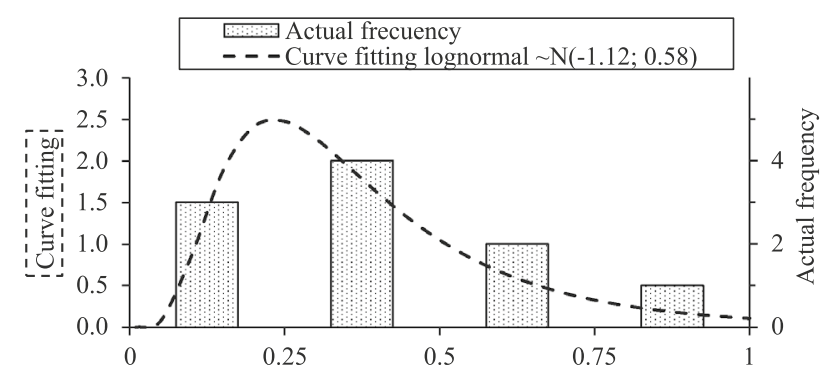

Fig. 6 Frequency distribution for the different intervals defined in Fig. 5. In addition, a fitting curve following a lognormal distribution
The random variable to be statistically analyzed is the relative position of the cumulative corrosion depth (occurred for a certain time period) in relation to the lower and upper bounds given in Fig. 5 for the same period. The dataset varies between 0.03 and 0.79 , where zero is the lower bound and one is the upper bound. One can verify whether a set of random observations $x_{1}, x_{2}, \ldots, x_{N}$ is lognormally distributed through a quantile-quantile plot. Once the data set has been sorted from lowest to highest, the quantile $f\left(x_{i}\right)$ value for a given observation $x_{i}$ corresponds to the fraction of observations in a data set whose values are below $x_{i}$. One method to calculate the corresponding quantile for each observation is through Eq. (2):

$\frac{(i-0.5)}{N}$.

Then, the lognormal quantile-quantile plot compares the inverse of the standard normal cumulative distribution of $f\left(x_{i}\right)$ on the horizontal axis with the natural logarithm of the corrosion observed $\ln \left(x_{i}\right)$ on the vertical axis. A straight trendline between these two data sets indicates a good representation of the lognormal distribution over the random observations. If this is the case, the slope of the straight trendline is the standard deviation of the lognormal distribution, while the intersection of the straight trendline with the vertical axis is the mean of the lognormal distribution. The results of the quantile-quantile plots are given in Fig. 7.

Since the sample size $N$ is 10 in Fig. 7a, each value along the horizontal axis becomes the inverse of the standard normal cumulative distributions of ten percentiles from 5 to $95 \%$ evenly spaced every $10 \%$. Figure 7 a considers the whole data set, and the statistical parameters obtained from the straight trendline can be used. However, for design purposes, it is convenient to prioritize a better calibration with the highest data values, since the latter values will control the design, as shown in Fig. 1. The principle behind this is that rock bolts with a higher corrosion rate will reach the allowable corrosion depth earlier. Therefore, Fig. $7 \mathrm{~b}$ is introduced, and the resulting trendline gives a lognormal distribution of $\sim N(-1.12,0.58)$. The comparison of this probability distribution with the original data set is shown in Fig. 6.

The last step to define a probability distribution for a given exposure time is to set how the $9 \%$ significance level is spread between the probability to get values above the upper bound and below the lower bound in Fig. 5. In this regard, the lognormal curve fitting shown in Fig. 6 gives a probability of $3 \%$ that the values will exceed one (where one represents the upper bound in Fig. 5); therefore, the resulting probability of obtaining values below the lower bound is $6 \%$. These probability distributions above the upper bound and below the lower bound will be extrapolated to longer exposure times. The prognosis of actual corrosion depth in 
steel at different exposure times in the described aggressive environments are given in Fig. 8.

The three exposure time curves given in Fig. 8 comply with a confidence level equal to $91 \%$ for the extreme corrosivity level CX band and the probability of exceeding its upper bound is $3 \%$.

\section{Useful Life Extension}

Based on the aggressive environments identified in Sect. 2, particular emphasis is placed on the lifespan extension that cement grouting, hot-dip galvanizing, and epoxy coating can provide to rock bolts in chloride-rich and acidic groundwaters. The case of dissolved oxygen content is addressed in the discussion chapter.

\subsection{Useful Life Extension by Cement Grouting}

It is well known that carbon steel embedded in cement/mortar/concrete has long-term protection. One of the reasons is the high $\mathrm{pH}$ environment, which strongly reduces the corrosion rate of steel (establishing a stable oxide film on the steel surface). Another important factor is that cement becomes a physical barrier for corrosion-promoting agents such as oxygen, water and the aggressive ions and biota it may hold.

Passivated carbon steel at a $\mathrm{pH}$ value of approximately 13 gives a corrosion rate $<1 \mu \mathrm{m} /$ year (Chitty et al. 2005). This is, of course, under ideal conditions with steel rebar embedded in nondegraded cement mortar and the absence of aggressive ions that can dissolve the oxide film on the steel surface. However, corrosive groundwater may promote a much faster corrosion rate.

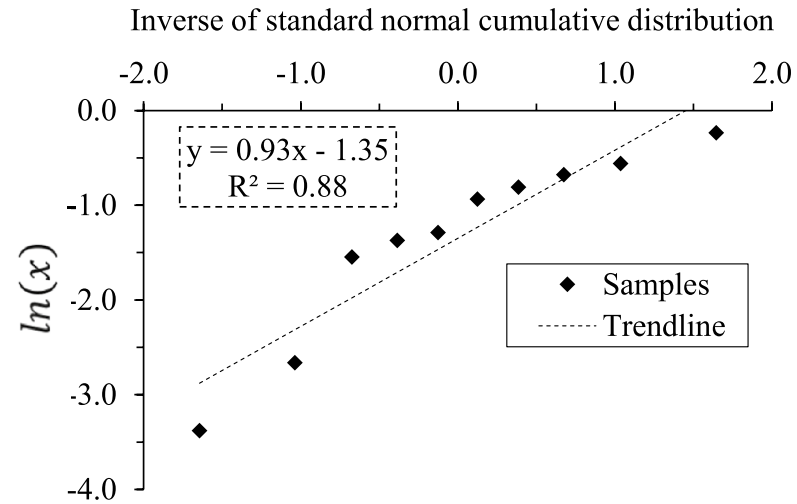

(a)

\subsubsection{Chloride Resistance of Cement Mortar}

Based on Fick's 2nd law of diffusion described by the International Federation for Structural Concrete (fib) (2006), which is given in Eq. (3), it is possible to roughly estimate the elapsed time until the onset of depassivation occurs at the bolt-grout interface due to chloride penetration in the cement mortar installed in chloride-rich groundwater.

$C\left(x_{\mathrm{c}}, t\right)=C_{\mathrm{s}}\left[1-\operatorname{erf}\left(\frac{x_{\mathrm{c}}}{2 \times \sqrt{D_{\text {app }}\left(t, T_{\text {real }}\right) \times t}}\right)\right]$.

A chloride concentration threshold value of $0.4 \%$ (wt $\%$ cement) is adopted for the start of depassivation at the boltgrout interface following typical design values in the US and Europe for reinforced concrete (Angst et al. 2009). A $C_{s}$ value equal to $2.9 \%$ (wt\% cement) is adopted from measured chloride profiles in uncracked sprayed concrete used for rock support in Norwegian subsea road tunnels (Hagelia 2018).

Considering a bolt borehole diameter of $45 \mathrm{~mm}$ and a rebar of $20 \mathrm{~mm}$, the $x_{c}$ value is fixed to $12.5 \mathrm{~mm}$.

The apparent coefficient of chloride diffusion through the grout mortar is given in Eq. (4) as follows:

$D_{\text {app }}\left(t, T_{\text {real }}\right)=D_{\text {app_28 }}\left(\frac{t_{\mathrm{o}}}{t}\right)^{\alpha} \cdot \exp \left(b_{\mathrm{e}}\left(\frac{1}{293}-\frac{1}{273+T_{\text {real }}}\right)\right)$.

The water cement $(w / c)$ ratio for expandable cement mortar varies by supplier and user. Today, the $w / c$ ratio for expandable mortar in rock bolts is restricted to 0.44 (NPRA 2018). In this regard, it is assumed that the chloride diffusion coefficient at 28 days for this kind of mortar is well represented by CEM I Portland cement with a $w / c$ ratio between 0.4 and 0.45 following the normal

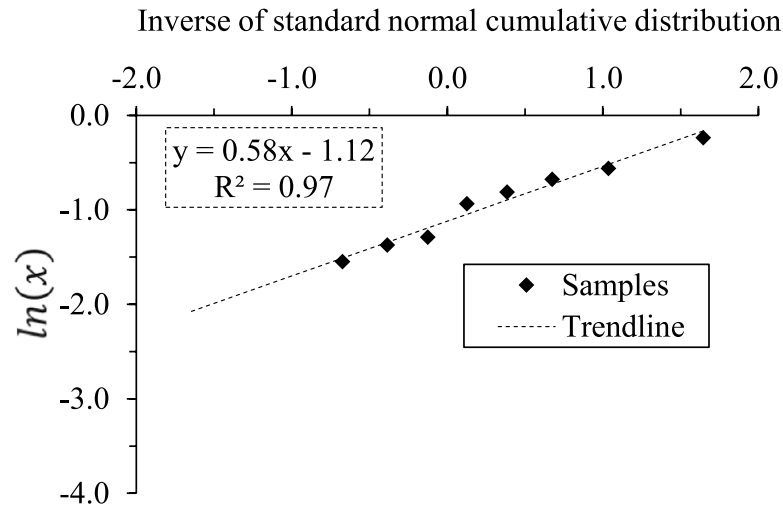

(b)

Fig. 7 Lognormal quantile-quantile plot: a shows the trendline for the 10 observations plotted in Fig. 6 , b shows a trendline for the highest 8 observed values 


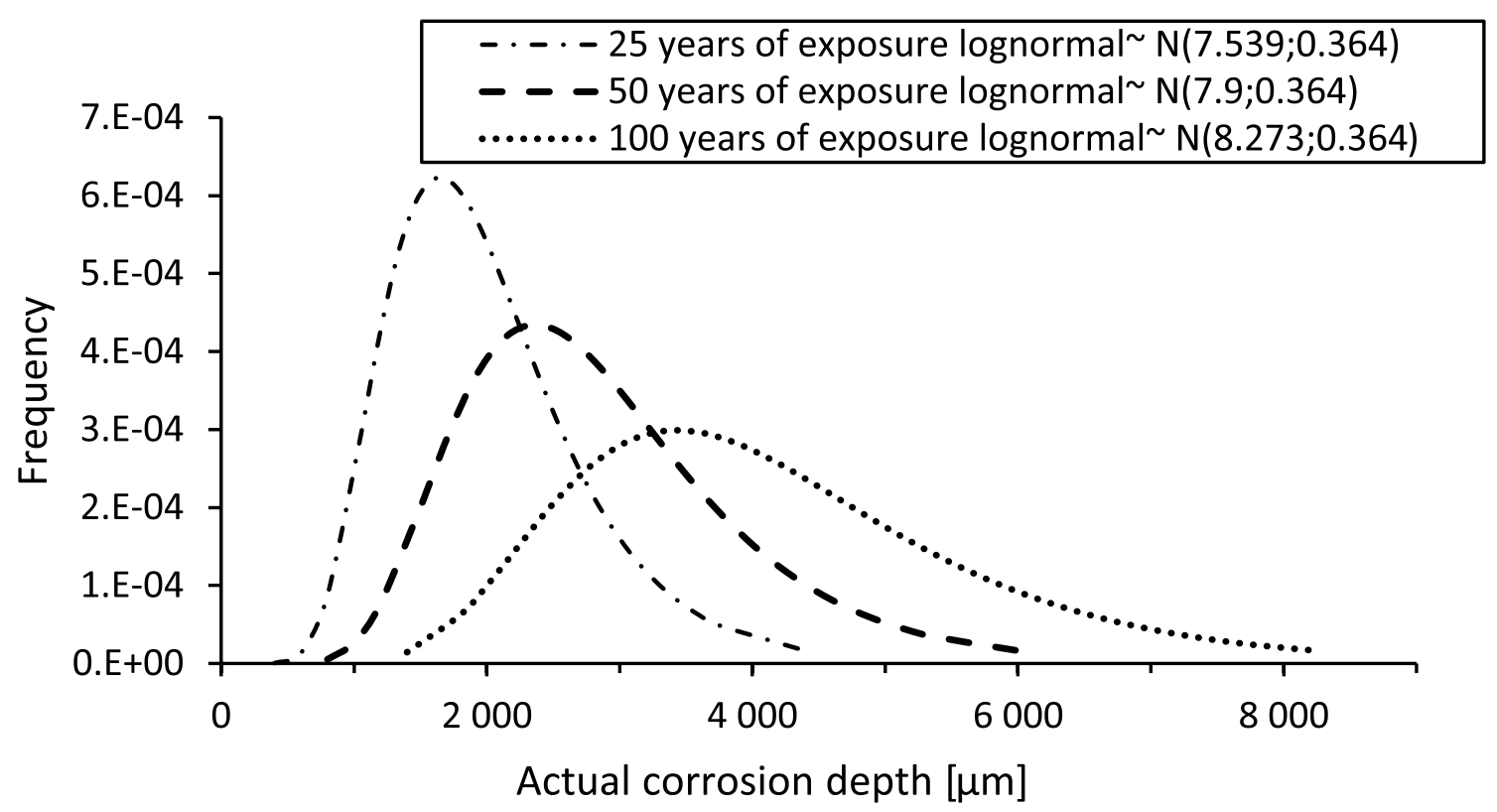

Fig. 8 Probability distributions for the actual corrosion depth expected in carbon steel exposed to the aggressive environments described in this research for 25,50 , and 100 years

distributions of $\mathrm{N}\left(8.9 \times 10^{-12} \mathrm{~m}^{2} / \mathrm{s} ; 1.78 \times 10^{-12} \mathrm{~m}^{2} / \mathrm{s}\right)$ and $\left(10 \times 10^{-12} \mathrm{~m}^{2} / \mathrm{s} ; 2 \times 10^{-12} \mathrm{~m}^{2} / \mathrm{s}\right)$ respectively, following fib (2006).

An $\alpha$ value equal to 0.3 is adopted according to fib (2006) for CEM I. The environmental transfer variable $b_{e}$ usually varies between 3300 and $5500 \mathrm{~K}$. A value of $4800 \mathrm{~K}$ is adopted, as suggested by fib (2006). The temperature $T_{\text {real }}$ of cement mortar varies with geographical location, tunnel length, ventilation type, traffic volume, frost protection applied, etc. Based on a random selection of Norwegian literature about the temperature conditions in tunnels (Luke 2013; Holter and Geving 2016) a temperature $T_{\text {real }}$ equal to $7{ }^{\circ} \mathrm{C}$ was chosen. The results are given in Fig. 9 .

In Fig. 9, the circles represent the predicted time for corrosion initiation. The range shown for each $w / c$ ratio corresponds to one standard deviation from the mean of the expected chloride diffusivity value

Based on this figure, the expected useful life extension of mortar in chloride-rich groundwater is less than one year, even for a $w / c$ ratio of 0.4 . After this period, the steel starts to corrode. Then, for practical purposes, the corrosion protection of cement grout against chloride penetration is considered negligible.

\subsubsection{Sulfuric Acid Resistance of Cement Mortar}

The pore solution in mortar has a high $\mathrm{pH}$, protecting the bolt rebar. However, under acid attack, the low $\mathrm{pH}$ front inside the mortar will reach the bolt surface at some stage. The degraded zone in the mortar also undergoes a decalcification process (Grandclerc et al. 2018). The evolution of the dissolved calcium content in hardened cement paste was studied in samples immersed in a sulfuric acid solution. Pavlík (1994) suggests Eq. (5) for the kinetics of concrete degradation for a given concentration of an acid:

$d=b \cdot \sqrt{t}$.

A comparison of the degradation kinetics of ordinary Portland cement (OPC) mortar/concrete samples under sulfuric acid attack measured in the laboratory exposed to stagnant water (samples submerged in sulfuric acid) and flowing water (circulating acidic water in the laboratory) is given in Fig. 10.

In stagnant water, the degradation kinetics are proportional to the square root of time, as described in Eq. (5), and the degradation kinetics in flowing water are approximately linear with time. It is important to highlight as well that the sulfuric acid concentration in both cases is quite high, resulting in extremely acidic solutions ( $\mathrm{pH} 1)$. In the same type of mortar shown in Fig. 10, Kawai et al. (2005) observed negligible degradation kinetics after 90 days with a lower sulfuric acid concentration $(0.06 \mathrm{~mol} / \mathrm{l})$ and a less acidic solution ( $\mathrm{pH} 2$ ). By considering an annulus grout thickness $x_{c}$ equal to $12.5 \mathrm{~mm}$, Fig. 10 indicates that the grout thickness may protect the rebar under flowing groundwater for only 3-5 months. In the case of stagnant acidic water, the projected lifespan extension is more than 13 years. 


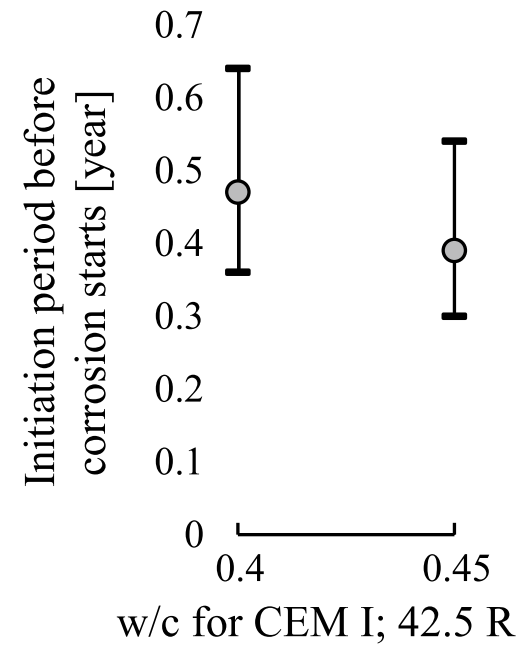

Fig. 9 Time elapsed before a critical chloride concentration reaches the grout/steel interface

\subsection{Useful Life Extension by Hot-Dip Galvanizing}

In the literature, several benefits of using hot-dip galvanizing for steel corrosion protection are described. A summary is given as follows:

- The zinc coating acts as a barrier to oxygen and moisture, which are reactants needed for steel corrosion (Darwin et al. 2009).

- Zinc provides cathodic protection. Zinc has a lower electrochemical potential than carbon steel in the galvanic series; therefore, zinc is more active, working as a sacrificial anode (Darwin et al. 2009).

- Zinc undergoes a lower corrosion rate than iron for the same environmental condition in an approximate ratio of 1-10, respectively (NS-EN ISO 9223 2012).

- Zinc has a higher average critical chloride content for the onset of depassivation by galvanic coating in comparison to unprotected steel (Darwin et al. 2009; Pernicova et al. 2017).

The standard NS-EN ISO 9224 (2012) describes longterm uniform corrosion of zinc with Eq. (1). However, the statistical parameter $n$ is 0.813 , which is close to 1 . Hence, all the corrosion rate results for zinc found in the literature will be analyzed by considering a linear behavior with time.

\subsubsection{Chloride Resistance Provided by Hot-Dip Galvanizing}

Table 2 shows the results of several corrosion rate studies of hot-dip galvanized steel. Measurements were collected in the following areas:

- Flat sheet specimens made of hot-dip galvanized steel located along tunnel walls near the road level (the Söderled \& Kvarnholm tunnels, Sweden)

- Hot-dip galvanized rebars left in predrilled boreholes (the Muskö and Äspö tunnels in Sweden and the Vardø tunnel in Norway)

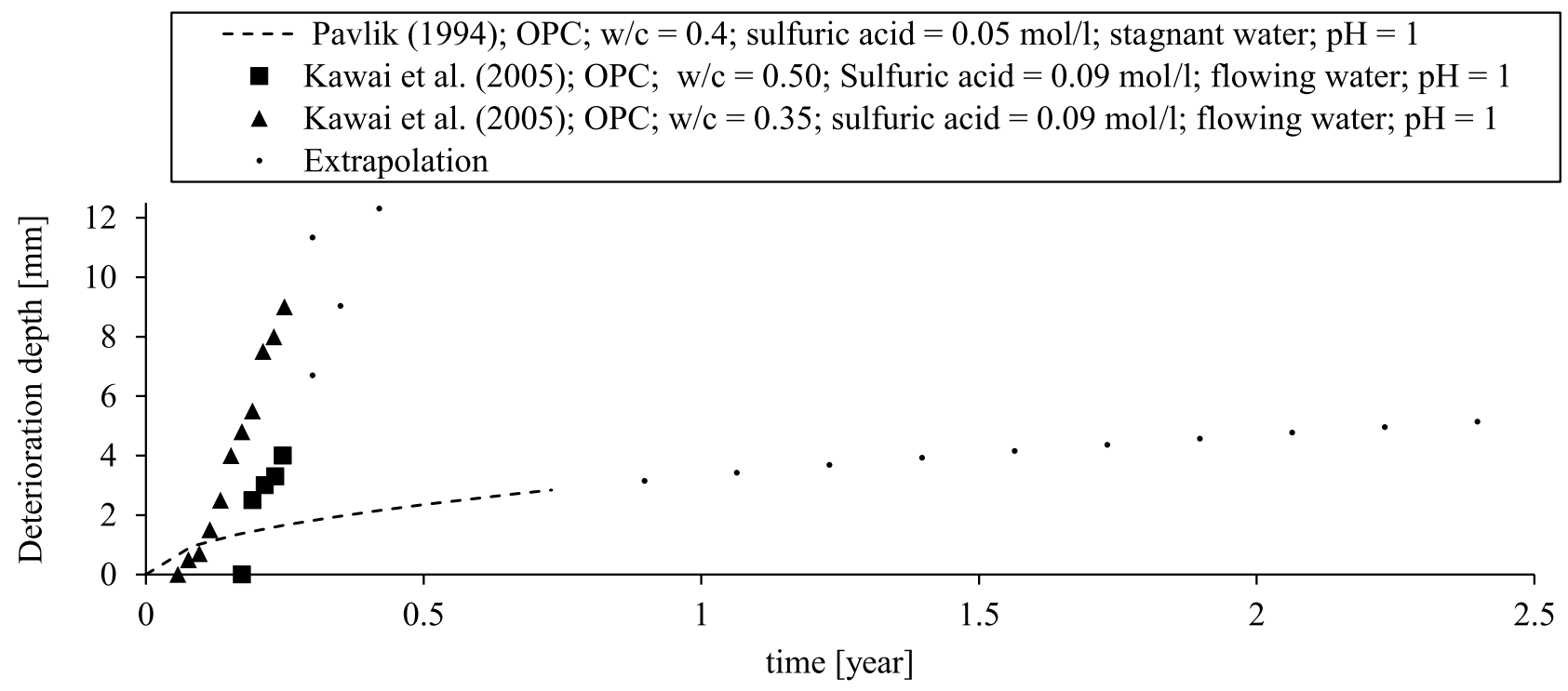

Fig. 10 Kinetics of degradation in hardened cement paste triggered by sulfuric acid (Pavlík 1994; Kawai et al. 2005). Extrapolation dots represent deterioration depth projections not given by the original source 
In addition, one case of hot-dip galvanized rebar submerged in oxygenated sea water in the laboratory is included.

The exposure to chloride given in Table 2 is due to either deicing salts, chloride-rich groundwater or sea water in the laboratory. The results in the Muskö and Äspö tunnels with chloride-rich groundwaters are provided twice. In one case, the results are related to ungrouted end rebar samples protruding from the rock contour, that is, exposed to atmospheric corrosion. Under these conditions, the corrosivity level of the rebar lies between the medium (C3) and high (C4). In the second case, the results come from the central stretch of the rebars that were grouted with cement mortar. In these conditions, the corrosivity level in both cases turned out to be extreme (CX). This is very likely due to the high $\mathrm{pH}$ environment triggered by the cement mortar with a very low $w / c$ ratio of approximately 0.3 . Then, the corrosion rate from the latter case should be considered with caution since the $w / c$ ratio of the cement grout is not usually that low. As a lower bound, 9 years seems to be a more reasonable value for the lifespan extension given by hot-dip galvanizing in chloride-rich groundwater. As a reference, the average of the useful life extensions given in Table 2 is 35 years.

\subsubsection{Sulfuric Acid Resistance Provided by Hot-Dip Galvanizing}

The comprehensive work carried out by Denison and Romanoff (1952) included the study of galvanized steel corrosion in samples buried in organic reducing acid soils. At one test site, the soil had a $\mathrm{pH}$ of 2.6. The exposure time of different samples in that soil varied between 2 and 13 years. Based on the weight loss of the galvanized steel, the equivalent corrosion rates exceeded $67 \mu \mathrm{m} /$ year in all cases.

More recently, Satola and Aromaa (2004) reported corrosion rates of galvanized steel strands in pyritic rock masses. The reported groundwater $\mathrm{pH}$ was 2.6. The corrosion rate was on the order of $1000 \mu \mathrm{m} /$ year. These results indicate that the contribution of hot-dip galvanizing to the lifespan extension of rock bolts is negligible in acidic environments.

\subsection{Useful Life Extension by Duplex Protection System}

In the duplex protection system, an epoxy coating is used as a topcoat after the steel is hot-dip galvanized. Organic coatings restrict the interaction of zinc with the environment. In turn, the zinc coating provides cathodic protection for the steel rebar.

Epoxy powder coating provides a good barrier against ions (Knudsen and Forsgren 2017). However, these coatings are not impermeable to oxygen and water (Sangaj and Malshe 2004). In addition, epoxy coatings are vulnerable to disbonding i.e., adhesion loss to the substrate, and aggressive ions can be transported under the disbonded coating. The exact mechanism behind the protection barrier provided by the epoxy coating to the metals is not fully understood (Sangaj and Malshe 2004). Organic coatings are a complex combination of binder, pigments, solvents, and other additives, which defines a unique epoxy resin network (Møller et al. 2017). Additionally, the epoxy coating can also undergo chemical degradation, changing its properties as a physical barrier against aggressive ions. Nevertheless, there are empirical proposals and observations that provide some insights into the corrosion protection given by epoxy coatings in chloride-rich and acidic environments.

\subsubsection{Chloride Resistance by the Duplex Protection System}

Eijnsbergen (1994) has proposed Eq. (6) to estimate the useful life of the duplex system protection in years of outdoor exposure, considering a limit state of $5 \%$ rust on the carbon steel substrate as follows:

$D_{\text {duplex }}=K \times\left(D_{\text {zinc }}+D_{\text {paint }}\right)$.

For a hot-dip galvanized coating with an average thickness of $85 \mu \mathrm{m}$, Eijnsbergen (1994) indicates that $D_{\text {zinc }}$ is approximately 30 years in the marine atmosphere. This is approximately the same as the average lifespan extension given in Table 2 for the same zinc thickness. However, a lower bound of 9 years, as discussed in Sect. 4.2.1, is possible.

With regard to $D_{\text {paint }}$ in Eq. (6), an epoxy coating thickness of $85 \mu \mathrm{m}$ provides a protection of 3 years in a marine atmosphere. The factor $K$ varies between 1.5 and 2.3, and the lower bound is the proper value for the most aggressive environments.

Notably, the corresponding limit state in Eq. (6) corresponds to $5 \%$ rust on the carbon steel. This is equivalent to a corrosion depth of $500 \mu \mathrm{m}$ around a rebar $20 \mathrm{~mm}$ in diameter. This corrosion depth in carbon steel may happen in 18 years, considering the duplex protection system with $85-\mu \mathrm{m}$-thick coating layers, and a synergistic factor $K$ equal to 1.5 .

Figure 5 indicates that a corrosion depth of $500 \mu \mathrm{m}$ in uncoated carbon steel can be achieved after approximately 4 years of exposure in marine environments. Hence, a rough estimate of the minimum lifespan extension by the duplex protection system is 14 years. This is considered the lower bound of lifespan extension by the duplex protection system. 


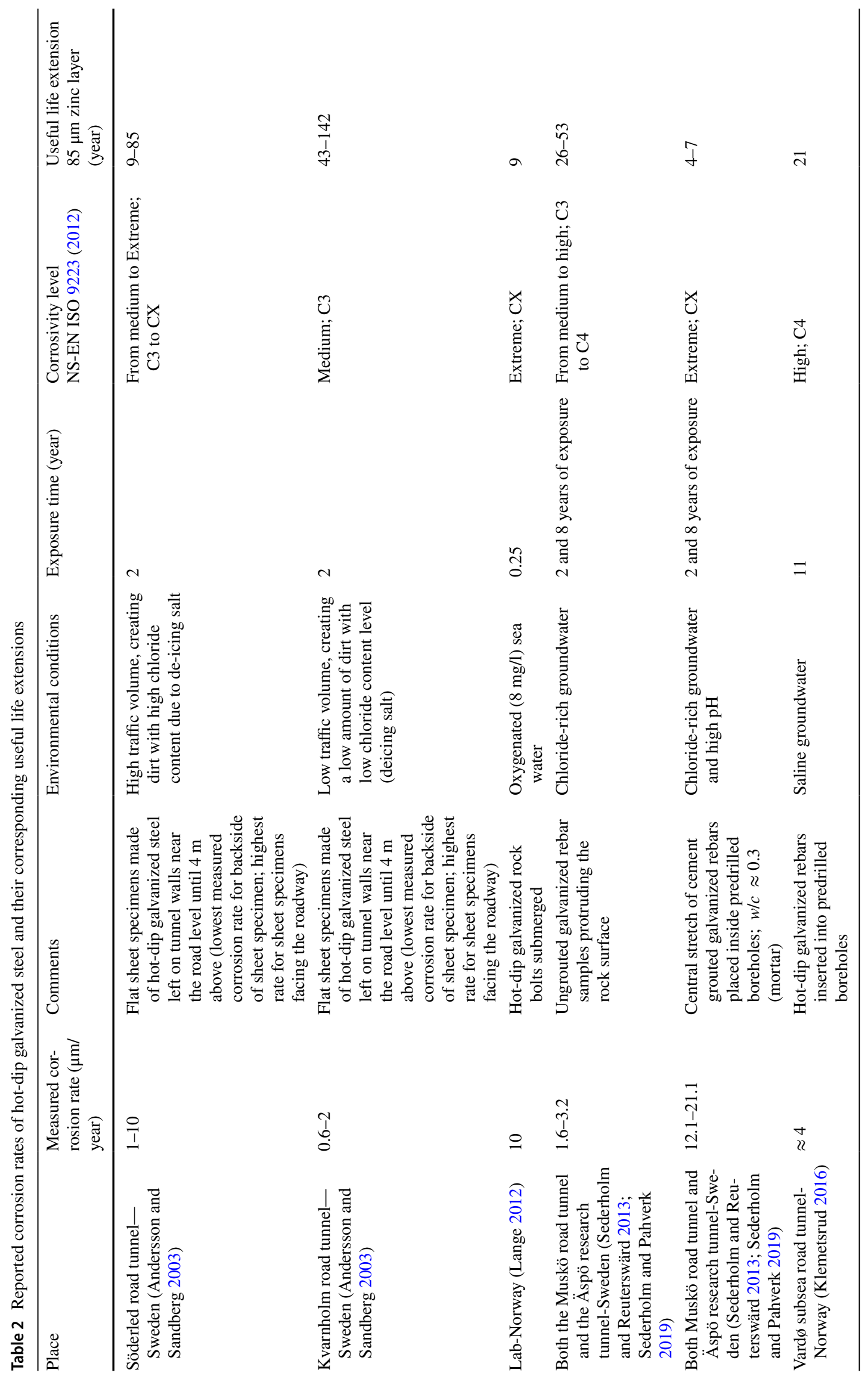




\subsubsection{Acid Resistance Provided by the Duplex Protection System}

If the organic coating is damaged in an acidic environment, the zinc coating is exposed, and there will not be any additional protection for the surrounding epoxy coating (Knudsen and Forsgren 2017). Nevertheless, it has been reported that undamaged organic coatings can provide excellent resistance against acids (Møller et al. 2017). Khodair et al. (2019) measured the corrosion rate of mild steel with and without epoxy coating in acidic and saline environments as shown in Fig. 11.

Figure 11 clearly shows the contribution of the epoxy coating to the reduction in the corrosion rate in acidic environments. The high corrosion level observed, particularly for those measurements with exposed steel, is related to the short exposure time of only $5 \mathrm{~h}$, during which time the oxide film starts to form. The performance of the epoxy-coated steel in saline and acidic solutions is also shown in Fig. 11. While the corrosion rate reduction of the epoxy-coated steel in the acidic environments is approximately $96 \%$ on average, the efficiency of the epoxy-coated steel in saline solutions is only $62 \%$.

Popović et al. (2005) tested the corrosion behavior of mild steel with and without epoxy coating using electrochemical impedance spectroscopy (EIS) in $0.1 \mathrm{~mol} / 1 \mathrm{sul}$ furic acid solution. Based on the corrosion current density determined in each sample, the equivalent corrosion rate is $1150 \mu \mathrm{m} /$ year for the exposed steel, while $149 \mu \mathrm{m} /$ year is the equivalent corrosion rate for the epoxy-coated steel after 500 $\mathrm{h}$ of exposure. That is, an $87 \%$ improvement in corrosion rate reduction was achieved with the epoxy coating. This result is consistent with Fig. 11 for epoxy coating protection in acidic environments.

\subsubsection{Some Experience with the Duplex Protection System}

Blistering of the epoxy coating in bolt accessories has been reported in subsea tunnels (Ongstad 2012). An illustration is given in Fig. 12. In some cases, steel corrosion was found behind the powder coating.
It is well known that epoxy coatings are is very sensitive to damage during handling and transportation (Manning 1996; Saguiés et al. 2010). A report described the setup of bolt corrosion research in the Oslofjord tunnel (Klemetsrud 2016), which considered painted galvanized steel bolts, observed unintended scratches and impurities in the epoxy coating after normal handling and before the test started. Research in the Muskö and Äspö tunnels also included the follow-up of epoxy-coated and hot-dip galvanized bolts. Intentional damage to the coating triggered adhesion loss of the epoxy coating after 8 years in some samples (Sederholm and Pahverk 2019). Nevertheless, duplex system coatings without preexisting damage to the rebars showed no deterioration after the same time period in the context of a chloride-rich environment.

\section{Discussion}

The parameter flowing groundwater conditions appears to be more relevant than previously considered in the classification of aqueous corrosive environments. Remarkable examples are Vietas, Haukeli, and Renström tunnels in Fig. 5, where corrosion rates meet the extreme corrosivity level CX without the groundwater having a low $\mathrm{pH}$ or a high salinity. In these tunnels, the steel was exposed to dripping groundwater. In this regard, the uniform corrosion rates on steel caused by flowing groundwater in some Australian mines studied by Villaescusa et al. (2007) gives corrosion rates that can be categorized as extreme corrosivity level CX. The requirement to reach this corrosivity level in these mines is flowing groundwater with a dissolved oxygen content exceeding $3 \mathrm{mg} / \mathrm{l}$. It is important to highlight as well that the fastest kinetics of degradation in mortar immersed in sulfuric acid shown in Fig. 10 is related to flowing water. In hotdip galvanizing, it is claimed that only $0.5 \mathrm{~m} / \mathrm{s}$ is enough to remove the oxide film deposited on the zinc surface (Thomas 1978). Running water can also cause grout defects by damaging the cement grout in its plastic stage (NPRA 1999). Thus, the parameter flowing groundwater conditions is a key variable that should explicitly be mentioned in any proposed
Fig. 11 Corrosion rates of mild steel immersed in different aqueous solutions for five hours at $30{ }^{\circ} \mathrm{C}$ with and without epoxy coating (Khodair et al. 2019)

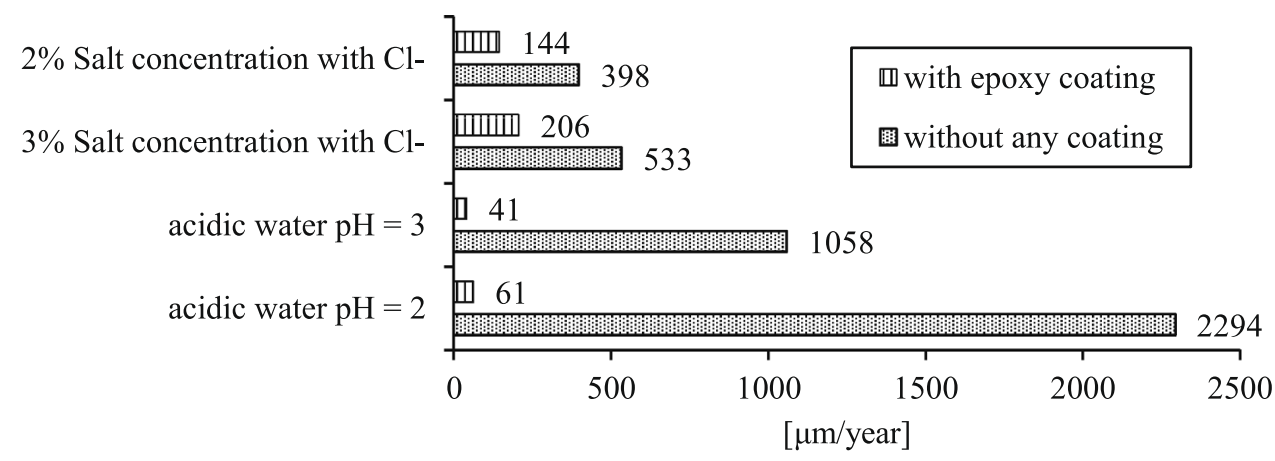




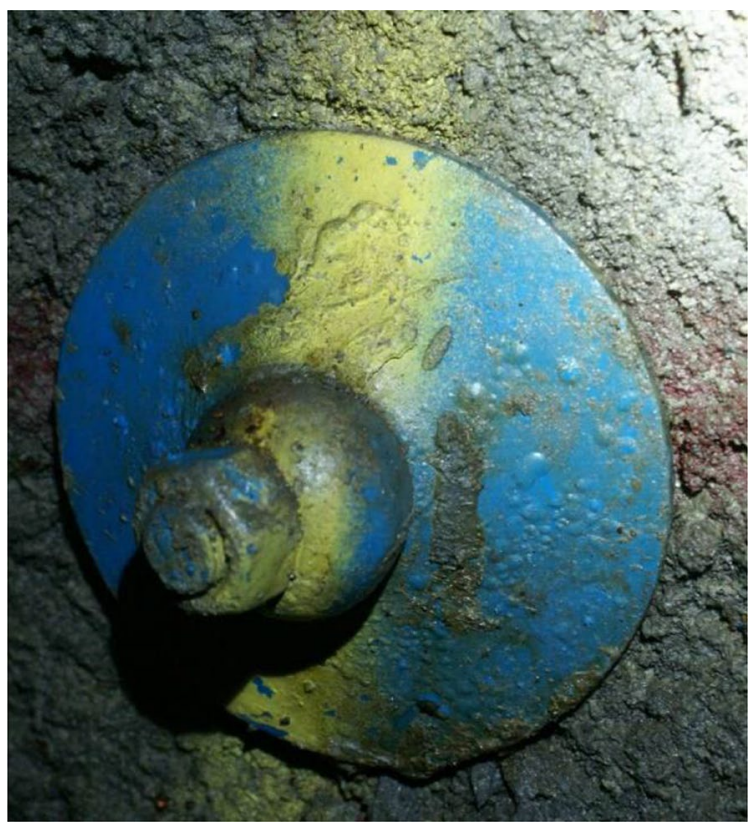

Fig. 12 Blisters observed in the rock bolt plate in the Oslofjord subsea road tunnel after 10 years of exposure (Ongstad 2012)

classification system regarding the corrosivity level of rock bolts. Nevertheless, it is important to highlight that the variability of flowing groundwater can be restricted with pregrouting works ahead of the tunnel face.

For a given exposure time, Fig. 8 gives a probability distribution for the expected corrosion depth in steel exposed to aggressive environments. From a design point of view, an important inquiry to be addressed is how often these grout defects will coincide with the peak working stresses in the rock bolt. In wet tunnel stretches with aggressive groundwater and rock mass deformation, corrosion will very likely take place where the highest axial stresses are induced along the rock bolt, for the following reasons:

- In hard rock, groundwater flows through mainly discontinuities (Coli and Pinzani 2014).

- In hard rock, deformation is controlled by the rock mass discontinuities, which might eventually crack the cement grout as an extension of the discontinuity (Sandberg and Lagerblad 2002).

- In fully grouted rock bolts, the peak axial stress occurs in the grout defects (Li 2017b).

Hence, it is considered adequate to use the probability distributions given in Fig. 8 for cement grouted rebars installed in aggressive environments if rock mass deformation is expected. One can extend the use of Fig. 8 if grout defects by other means are foreseen in aggressive environments. Finally, Fig. 8 can also be applied for uncoated steel rebars fully grouted with cement in chloride-rich environments, even without grout defects, since the protection provided by cement mortar for the steel rebar is negligible in this environment.

For the rock bolts used today (with the duplex protection system and postgrouted), to derive a probability distribution for the long-term corrosion depth in the steel rebar or steel tube is more challenging. There is a complex interaction between the different protection elements, the steel and the different environments. In addition, the field experience is more limited than the case of cement grouted rebars. Nevertheless, the collected experiences in Sect. 4 indicate that epoxy coating and cement grouting protect better the steel rebar in acidic than in chloride-rich environments. On the other hand, hot-dip galvanizing provides higher protection in chloride-rich than in acidic environments. However, for the zinc thickness of $85 \mu \mathrm{m}$ considered, it is inferred that the joint performance of the epoxy coating, hot-dip galvanizing, and cement grouting is better in acidic than in chloride-rich environments. Thus, a ranking from the most to the least unfavorable condition can be established for the rock bolts used today:

1. Chloride-rich environment with grout defects.

2. Chloride-rich environment without grout defects.

3. Acidic environment with grout defects.

4. Acidic environment without grout defects.

Apart from creating grout defects, deformable rock mass increases the risk of failure by inducing loads to the rock bolts. Considering that the type of rock bolts used these days are usually pretensioned and installed near the tunnel face, the extra load exerted by the rock mass limits further the allowable corrosion depth in these rock bolts. Overall, the rock bolts used today installed in subsea tunnels with expected deformation of the rock mass are of particular concern.

\section{Conclusions}

For rock bolts, the aggressive groundwater conditions identified in Nordic road tunnels are as follows:

1. Subsea tunnels with marine groundwater.

2. Groundwater with a pH below four (because of sulfuric acid formation due to the oxidation of the pyrite mineral in the rock).

3. Flowing groundwater conditions with a high concentration of dissolved oxygen.

In addition, deicing salts provide aggressive atmospheric conditions within the tunnel room. Any of these 
environments might lead to the highest corrosivity level established in international standards, which is comparable to the most polluted industrial areas. Regarding the conditions described, the parameter representing the flowing groundwater conditions has not been consistently described in the literature properly and has even been overlooked in some references.

For 25,50 , and 100 years of exposure time, a probability distribution is derived for the stochastic corrosivity level of exposed steel in the described aggressive environments, taking advantage of the good fit between the corrosion observed in underground structures and the extreme corrosivity level CX described in international standards. This is considered a valuable input for the durability design of rock bolts.

The analysis on corrosion protection given by the duplex protection system and cement grouting for the rock bolts used these days indicates that those installed in subsea tunnels with deformable rock mass are of particular concern to achieve a useful life of 100 years.

Funding Open access funding provided by NTNU Norwegian University of Science and Technology (incl St. Olavs Hospital - Trondheim University Hospital)

\section{Compliance with Ethical Standards}

Conflict of interest The authors declare that they have no conflict of interest.

Consent for publication All authors read and approved the final manuscript.

Open Access This article is licensed under a Creative Commons Attribution 4.0 International License, which permits use, sharing, adaptation, distribution and reproduction in any medium or format, as long as you give appropriate credit to the original author(s) and the source, provide a link to the Creative Commons licence, and indicate if changes were made. The images or other third party material in this article are included in the article's Creative Commons licence, unless indicated otherwise in a credit line to the material. If material is not included in the article's Creative Commons licence and your intended use is not permitted by statutory regulation or exceeds the permitted use, you will need to obtain permission directly from the copyright holder. To view a copy of this licence, visit http://creativecommons.org/licenses/by/4.0/.

\section{References}

Andersson P, Sandberg B (2003) The corrosive environment in road tunnels and investigation of rock bolts from Vindö tunnel. In: Swedish Rock Engineering research, SveBeFo. Annual Rock Mechanics meeting, Stockholm

Angst U, Elsener B, Larsen CK, Vennesland Ø (2009) Critical chloride content in reinforced concrete-a review. Cem Concr Res 39:1122-1138. https://doi.org/10.1016/j.cemconres.2009.08. 006
Bobet A (2009) Elastic solution for deep tunnels. Application to excavation damage zone and rockbolt support. Rock Mech Rock Eng 42:147-174. https://doi.org/10.1007/s00603-007-0140-0

Broch E, Grøv E, Davik KI (2002) The inner lining system in Norwegian traffic tunnels. Tunn Undergr Sp Technol 17:305-314. https:// doi.org/10.1016/S0886-7798(02)00026-3

Castaño JG, de la Fuente D, Morcillo M (2007) A laboratory study of the effect of $\mathrm{NO}_{2}$ on the atmospheric corrosion of zinc. Atmos Environ 41:8681-8696. https://doi.org/10.1016/j.atmosenv.2007. 07.022

Chitty WJ, Dillmann P, L'Hostis V, Lombard C (2005) Long-term corrosion resistance of metallic reinforcements in concrete-a study of corrosion mechanisms based on archaeological artefacts. Corros Sci 47:1555-1581. https://doi.org/10.1016/j.corsci.2004.07. 032

Coli M, Pinzani A (2014) Tunnelling and hydrogeological issues: a short review of the current state of the art. Rock Mech Rock Eng 47:839-851. https://doi.org/10.1007/s00603-012-0319-x

Darwin D, Browning J, O'Reilly M et al (2009) Critical chloride corrosion threshold of galvanized reinforcing bars. ACI Mater J 106:176-183. https://doi.org/10.14359/56465

Davik KI (1997) Proper use of sprayed concrete in tunnels. Final report. In: Norwegian Public Roads Administration (In Norwegian)

Denison IA, Romanoff M (1952) Corrosion of Galvanized Steel in Soils. J Res Natl Bur Stand (1934)

DIN 50929 part 3 (1985) DIN 50929 part 3. Probability of corrosion of metalic materials when subject to corrosion from the outsideburied and underwater pipelines and structural components

Dorion JF, Hadjigeorgiou J (2014) Corrosion considerations in design and operation of rock support systems. Trans Inst Min Metall Sect A Min Technol 123:59-68. https://doi.org/10.1179/17432 86313Y.0000000054

Eijnsbergen JFH (1994) Duplex Systems: Hot-dip galvanizing plus painting. Elsevier Science B.V.

EN 1990:2002 (2002) Eurocode: basis of structural design

Espedal TG, Nærum G (1992) The Rennfast Link at the Western coast of Norway with world's longest an deepest sub sea road tunnel. In: Subsea Tunnelling. Norwegian Tunnelling Society Publication 08 .

fib (2006) Model code for service life design. International federation for structural concrete

Grandclerc A, Dangla P, Gueguen-Minerbe M, Chaussadent T (2018) Modelling of the sulfuric acid attack on different types of cementitious materials. Cem Concr Res 105:126-133. https://doi.org/10. 1016/j.cemconres.2018.01.014

Grimstad E, Pedersen B (1986) Long time effect on resin end-anchored and cement grouted rock bolts. Preliminary experiences. In: Annual conference of the Norwegian Tunnelling Society, 1986 (in Norwegian)

Hadjigeorgiou J, Savguira Y, Thorpe SJ (2020) Impact of steel properties on the corrosion of expandable rock bolts. Rock Mech Rock Eng 53:705-721. https://doi.org/10.1007/s00603-019-01939-w

Hagelia P (2008) Deterioration mechanisms and durability of sprayed concrete in Norwegian tunnels. NFF Publication No. 17: underground openings - operations, maintenance and repair

Hagelia P (2018) Durability development for sprayed concrete as rock support in different tunnel environments. Norwegian Public Roads Administration. Report No. 566

Hassell RC, Kinsela B, Villaescusa E (2004) Corrosion assessment of ground support systems. In: Villaescusa E, Potvin Y (eds) Fifth international symposium on ground support, ground support in mining and underground construction, 28-30 September, Perth, Australia. Balkema, Rotterdam, pp 529-544

Helfrich HK (1989) The durability of rockbolts. Follow-up of rockbolts, belonging to different type and age, at the sandstone mine of Kvarntorp, central Sweden. Annual rock mechanics meeting in Stockolm 
Holmøy KH, Lien JE, Palmstrøm A (2009) The Frøya tunnel—going subsea on the brink of the continental shelf. In: NFF Publication No. 18: Subsea Tunnels

Holter KG, Geving S (2016) Moisture transport through sprayed concrete tunnel linings. Springer, Vienna

Indrehus O, Vassbotn P (2001) CO and NO2 pollution in a long two-way traffic road tunnel: investigation of $\mathrm{NO} 2 / \mathrm{NOx}$ ratio and modelling of NO2 concentration. J Environ Monit 3:221-225. https://doi.org/10.1039/b009493p

ISO 13823 (2008) General principles on the design of structures for durability

Kawai K, Yamaji S, Shinmi T (2005) Concrete deterioration caused by sulfuric acid attack. Durab Build Mater 20:5-9

KFF (1973) Practical handbook in rock bolting. Royal Norwegian Council for Scientific and Industrial Research. Office for Rock Blasting Technique (in Norwegian)

Khodair ZT, Khadom AA, Jasim HA (2019) Corrosion protection of mild steel in different aqueous media via epoxy/nanomaterial coating: preparation, characterization and mathematical views. J Mater Res Technol 8:424-435. https://doi.org/10.1016/j.jmrt. 2018.03.003

Klemetsrud K (2016) Corrosion test on rock bolts in the Oslo-fjord tunnel. Norwegian Public Roads Administration. Report No. 466 (in Norwegian)

Kløve B, Kvitsand HML, Pitkänen T et al (2017) Aperçu des ressources en eau souterraine et des systèmes d'approvisionnement en eau, et pollution microbienne associée, en Finlande, Norvège et Islande. Hydrogeol J 25:1033-1044. https://doi.org/10.1007/ s10040-017-1552-x

Knudsen $О \varnothing$ (2015) Corrosion protection in tunnels. Norwegian Public Roads Administration. Report No. 410 (in Norwegian)

Knudsen OØ, Forsgren A (2017) Corrosion control through organic coatings. Taylor \& Francis Group, New York

Lange T (2012) Bolts for rock support-laboratory tests of corrosion protection. Norwegian Public Roads Administration. Report No. 97 (in Norwegian)

Leygraf C, Wallinder IO, Tidblad J, Graedel T (2016) Atmospheric corrosion, 2nd edn. Wiley, New York

Li CC (2000) Durability of rock bolts-verification of two classification systems with regard to the corrosivity of environments. In: Swedish Rock Engineering research, SveBeFo.Report 46

Li CC (2017a) Principles of rockbolting design. J Rock Mech Geotech Eng 9:396-414. https://doi.org/10.1016/j.jrmge.2017.04. 002

Li CC (2017b) Rockbolting: principles and applications

Luke J (2013) Survey of environmental conditions in tunnels. The Hell tunnel, the Ekeberg tunnel and the Smestad tunnel

Manning DG (1996) Corrosion performance of epoxy-coated reinforcing steel: North American experience. Constr Build Mater 10:349-365. https://doi.org/10.1016/0950-0618(95)00028-3

Martinussen A (2008) Degradation of earlier reinforcement and support. In: NFF Publication No. 17: Underground openings-operations, maintenance and repair, pp 35-37

Melchers RE, Petersen RB (2018) A reinterpretation of the Romanoff NBS data for corrosion of steels in soils. Corros Eng Sci Technol 53:131-140. https://doi.org/10.1080/1478422X.2017.1417072

Møller VB, Dam-Johansen K, Frankær SM, Kiil S (2017) Acidresistant organic coatings for the chemical industry: a review. J Coat Technol Res 14:279-306. https://doi.org/10.1007/ s11998-016-9905-2

NILU (1990) Tromsøysundet Tunnel: asessment of air pollution. Norwegian Institute for Air Research

NPRA Northland (1990) Norms about road tunnels. Recommendations to the handbook 021
NPRA (1981) Handbook 025: Standard Code of Process 1: Roadworks. Norwegian Public Roads Administration, Main Process 7: completion and special works (in Norwegian)

NPRA (1992) Handbook 021: Road Tunnels. Norwegian Public Roads Administration (in Norwegian)

NPRA (1999) Rock bolt handbook 215. Norwegian Public Roads Administration (in Norwegian)

NPRA (2012) Handbook R761 Standard Code of Process 1: road contracts. Norwegian Public Roads Administration, Main Process 3: Tunnels (in Norwegian).

NPRA (2016a) Handbook N500: road tunnels. Norwegian Public Roads Administration (in Norwegian)

NPRA (2016b) Environmental loads in road tunnels. Norwegian Public Roads Administration. Report No. 577 (in Norwegian)

NPRA (2016c) Best practice for tunnel lining. Norwegian Public Roads Administration. Report No. 510 (in Norwegian)

NPRA (2018) Handbook R761 Standard Code of Process 1: road contracts. Norwegian Public Roads Administration, Main Process 3: Tunnels (in Norwegian)

NS-EN ISO 9223 (2012) Corrosion of metals and alloys. Corrosivity of atmospheres. Classification, determination and estimation, 2012

NS-EN ISO 9224 (2012) Corrosion of metals and alloys. Corrosivity of atmospheres. Guiding values for the corrosivity categories. Standard Norge

NS-EN-ISO-9223 (2012) Corrosion of metals and alloys. Corrosivity of atmospheres. Classification, determination and estimation. Standard Norge

Ongstad A (2012) Useful life of rock bolts. Norwegian Public Roads Administration. Major research and development project: modern road tunnels 2008-2011. Report No. 164

Pavlík V (1994) Corrosion of hardened cement paste by acetic and nitric acids part I: calculation of corrosion depth. Cem Concr Res 24:551-562. https://doi.org/10.1016/0008-8846(94)90144-9

Pedersen KB, Hafsaas G (1991) Overcoring and quality control of rock bolts. In: Annual conference of theNorwegian Tunnelling Society (in Norwegian)

Pells P, Bertuzzi R (1999) Permanent rockbolts-the problems are in the detail. In: Tenth Australian tunnelling conference. Melbourne, Vic, 21-24 March 1999

Pernicova R, Dobias D, Pokorny P (2017) Problems connected with use of hot-dip galvanized reinforcement in concrete elements. Proced Eng 172:859-866. https://doi.org/10.1016/j.proeng.2017.02.086

Popović MM, Grgur BN, Mišković-Stanković VB (2005) Corrosion studies on electrochemically deposited PANI and PANI/epoxy coatings on mild steel in acid sulfate solution. Prog Org Coat 52:359-365. https://doi.org/10.1016/j.porgcoat.2004.05.009

Romanoff M (1957) Underground Corrosion. U.S. Department of Commerce. National Bureau of Standards. Circular 579

Roy JM, Preston R, Bewick RP (2016) Classification of aqueous corrosion in underground mines. Rock Mech Rock Eng 49:3387-3391. https://doi.org/10.1007/s00603-016-0926-z

Sagüés AA, Lau K, Powers RG, Kessler RJ (2010) Corrosion of epoxycoated rebar in marine bridges-Part 1: a 30-year perspective. Corrosion 66:0650011-06500113

Sandberg B, Lagerblad B (2002) Durability of cement grouted rock bolts. Swedish Rock Engineering research, SveBeFo

Sangaj NS, Malshe VC (2004) Permeability of polymers in protective organic coatings. Prog Org Coat 50:28-39. https://doi.org/ 10.1016/j.porgcoat.2003.09.015

Satola I, Aromaa J (2004) The corrosion of rock bolts and cable bolts. In: Ground support in mining and underground construction-Villaescusa \& Potvin

Sederholm B, Pahverk H (2019) Corrosion testing of different types rock bolts in tunnels-long time exposure. In: Befo. Report 193 (in Swedish) 
Sederholm B, Reuterswärd P (2013) Corrosion testing of different types of rock bolts. In: Befo. Rock Engineering Research Foundation. Report 127 (in Swedish)

Seither A, Eide PE, Berg T, Frengstad B (2012) The inorganic drinking water quality of some groundwater works and regulated wells in Norway. Geological Survey of Norway, NGU

Stille H, Palmström A (2018) Practical use of the concept of geotechnical categories in rock engineering. Tunn Undergr Sp Technol 79:1-11. https://doi.org/10.1016/j.tust.2018.04.035

Sundholm S, Forsen O (1995) Corrosion tests on cement grouted bolt. In: Annual conference of the Swedish Rock Engineering Research, SvebeFo
Swedish Transport Administration (2016) Tunnel construction requirements. Trafikverket (in Swedish)

Thomas R (1978) Hot-dip galvanizing. Nordic Galvanizing Association, Oslo (in Norwegian)

Villaescusa E, Hassell R, Thompson A (2007) Corrosion of rock reinforcement in underground excavations. Minerals and Energy Research Institute of Western Australia. Report No. 263

Xia N, Liang RY, Payer J, Patnaik A (2013) Probabilistic modelling of the bond deterioration of fully-grouted rock bolts subject to spatiotemporally stochastic corrosion. Struct Infrastruct Eng 9:1161-1176. https://doi.org/10.1080/15732479.2012.670649

Publisher's Note Springer Nature remains neutral with regard to jurisdictional claims in published maps and institutional affiliations. 